\title{
EchoGéo
}

48 | 2019

Illegal cannabis cultivation in the world

\section{Marijuana and hashish: perspectives on cannabis}

Editorial

Jean-Louis Chaléard

CpenEdition

Journals

Electronic version

URL: https://journals.openedition.org/echogeo/17774

DOI: $10.4000 /$ echogeo. 17774

ISSN: 1963-1197

Publisher

Pôle de recherche pour l'organisation et la diffusion de l'information géographique (CNRS UMR 8586)

Electronic reference

Jean-Louis Chaléard, "Marijuana and hashish: perspectives on cannabis", EchoGéo [Online], 48 | 2019, Online since 05 September 2019, connection on 01 August 2021. URL: http://journals.openedition.org/ echogeo/17774 ; DOI: https://doi.org/10.4000/echogeo.17774

This text was automatically generated on 1 August 2021.

EchoGéo est mis à disposition selon les termes de la licence Creative Commons Attribution - Pas d'Utilisation Commerciale - Pas de Modification 4.0 International (CC BY-NC-ND) 


\section{Marijuana and hashish: perspectives on cannabis}

Editorial

Jean-Louis Chaléard

1 This is issue of Echogéo is special. First of all because it tackles a unique theme, the production of cannabis, but also because its articles are all written in English. While this journal is predominantly in French, not all contributions are written in this language. More importantly, research on cannabis and the majority of the scholarly output on this topic is published in English. For this reason, we decided to publish the entire "Sur le champ" section in this language. However, the "Sur l'écrit" section remains in French.

2 In his introduction, Pierre-Arnaud Chouvy, the editor of the section on global cannabis production, stresses this topic's relatively poor scholarly coverage, in particular in geography. This situation appears paradoxical, as cannabis is the most widespread illicit crop in the world: this issue is an attempt to fill this gap.

While this issue's eight articles do not aspire to provide an exhaustive overview, they do offer a wide panorama of cannabis production, ranging from the North (USA, Europe) to the South, spanning both Africa and Asia, and covering regions where cannabis is predominantly consumed as "weed" (dried leaves, flowers and stems), better known under its Mexican denomination marijuana and more commonly used in the USA, as well as countries such as France and Spain where cannabis resin (hashish) is more widely consumed and imported in particular from Morocco. The contributors document very diverse situations, conditions of production and productive trajectories, making any attempt at a generalization difficult. For instance, contrary to many accounts, cannabis is not only produced by poor farmers in Southern countries: other producers include self-supplying small growers in North America and Europe, as well as the development of large producer corporations. Furthermore, the production of this crop does not only thrive in war-torn countries... However, a number of common features can be observed: many producer areas are characterized by a relatively longestablished production and consumption (which sometimes goes back centuries), and 
have undergone major changes in recent years due to the expansion of culture and to the growth of demand.

4 The contributions tackle vast regions, providing valuable insights on a global or continental scale, but also examine specific cases in detail in order to study the issue in more depth. The first paper by P.A. Chouvy looks at heritage, current trends and challenges in global cannabis production. The author stresses that the data is often limited and unreliable, which poses problems in analyzing current production issues in a context of rapidly evolving activity and regulations. The following three papers address the topic in Africa. C. Duvall identifies four phases in the history of cannabis on this continent. The long existence of this production explains the depth of local knowledge and the wide range of crops cultivated today. The authorization and later the ban of production by colonial authorities have in fact facilitated its development in the twentieth century, making it very attractive for small farmers. Finally, C. Duvall highlights how the current legalization of production in several countries does not change the relations that have so far allowed the North to profit from the produce of African farmers.

5 The next two articles complement the first by elaborating on some specific points. J. Bloomer analyzes the context of cannabis production in Lesotho, examining its long existence and the part it plays in small farmers' survival strategies. J. Bloomer questions the consequences of a recent announcement by the government that this production could be licensed for medical purposes. A. Laudati shows that contrary to what is often claimed, cannabis production in Congo is not the cause of the country's current poor security situation, but rather a response to it. It is the ban of the cannabis trade and its illegality that shapes the terms of this market, rather than the opposite. J. Bradford and D. Mansfield take us to another continent, looking at the case of Afghanistan, a country well known for its opium production. The authors note that alongside opium, the country has for centuries been host to an established production of cannabis, which forms a significant part of the Afghani economy and culture. After the 1960s, the rise in the demand for hashish contributed to the development of global networks, as the cannabis trade transformed itself in response to local, national and global factors.

6 Looking at the case of a Northern country, N. Johnson seeks to understand how the USA have become a leading producer of cannabis in the late twentieth and early twenty-first century. Johnson shows the processes that led to the generalization of its cultivation in the country by analyzing the cases of three regions (Midwest, South and West), whose specific trajectories shed light on the reason why certain States are now legalizing this culture after an eighty-year long prohibition. Although Europe's production is not as significant as North America's, it has been growing since the 1960s and 70s. M. Gandilhon, N.Lalam and D. Weinberger analyze this evolution, along with the structural changes it brought about: the sector involves many diverse stakeholders, but remains dominated by players linked to Mafia organizations. However, small growers, whose practices are based on conviviality, account for a significant share of the production.

7 The last article by P.-A. Chouvy closes this issue with elements on past and current spatial dynamics. Working from concrete cases (Morocco, Afghanistan, North-East India, Burma, USA), the author identifies three main scenarios in large-scale drug crop cultivation today: that of a full-fledged but inefficient war on drugs; that of toleration, 
for various motives, of illegal drug plant cultivation by the state; and that of the militarily-challenged state that cannot exert full control over its territory. The war on drugs appears doomed to fail, which implicitly raises questions on the illegality of this practice. The article refers to a number of issues that emerge recurrently throughout other contributions, in the context of drugs and beyond: the relation between the illegal and the illicit for populations that have been cultivating cannabis for generations and were banned from doing so; the increasingly pressing question of the legalization of cannabis consumption, whether for medical purposes or not, which may have a major impact on third world producer countries...

Within this English-language issue on cannabis, the "Sur l'écrit" section retains its usual format and themes. Serge Weber interviews novelist-geographer (or geographernovelist?) J.-B. Maudet on his recently published novel, Matador Yankee, staging a character who was born at the border between two worlds: he is not quite a torero nor quite a cowboy. Beyond the character's story, the interview is an opportunity to discuss the gigantic and multidimensional US-Mexico border, as well as the relation between corrida and rodeo as the author is a bull fighting expert. The interview features many geographic notions: the spatial dimension of the arenas, the role of the immigrant Portuguese community in bull rearing in the USA, etc. However, J.-B. Maudet stresses that his novel is totally different from a historic or geographic novel, even though his thorough knowledge of the region has enabled him to skip the documentation phase when writing the novel. Beyond geographic considerations, the interview introduces a reflection on the influence of North American writers (such as Carver and Hemingway) and film. The interview thus paints a different picture of the American West and USMexico relations, in contrast with the images glimpsed through the prism of the cannabis trade. 